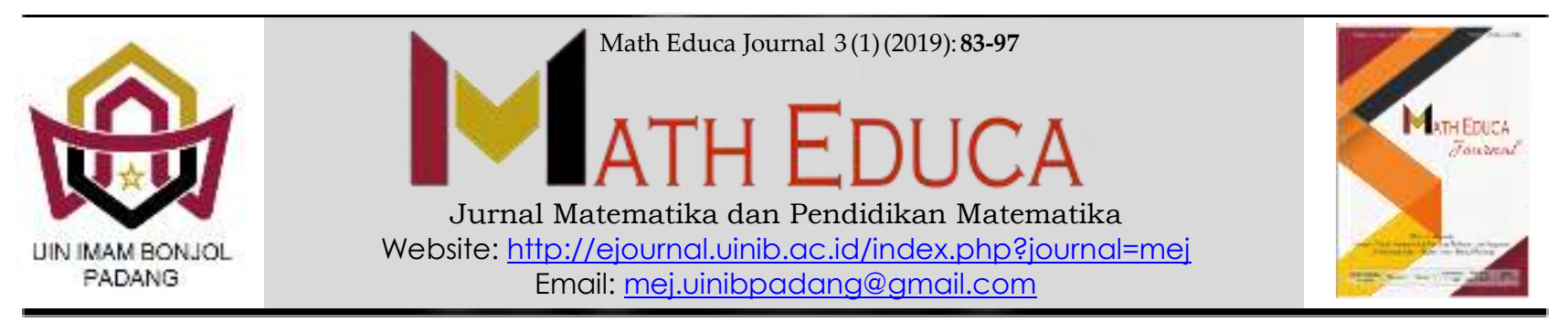

\title{
PENINGKATAN PROFESIONALISME GURU MATEMATIKA MTS/SMP PESISIR SELATAN MELALUI PELATIHAN MERANCANG PENILAIAN PADA KURIKULUM 2013
}

\author{
'Wan Nasir, ${ }^{2}$ Nita Putri Utami \\ 1 Balai Diklat Keagamaan Padang, Indonesia \\ 2 Tadris Matematika, Fakultas Tarbiyah dan Keguruan, UIN Imam Bonjol Padang, Indonesia \\ Email: 'wannasirwibdkpdg@gmail.com, ${ }^{2}$ nitautami030492@yahoo.com
}

Received: January 2019; Accepted: March 2019; Published: April 2019

\begin{abstract}
Abstrak
Analisis situasi pada lapangan memberikan gambaran bahwa penilaian yang digunakan oleh guru Matematika MTS/SMP pada kurikulum 2013 belum terlaksana secara optimal. Salah satu penyebab masih minimnya pemahaman guru Matematika MTS/SMP tentang penilaian yang ada pada kurikulum 2013. Selain itu, karena terlalu banyak guru SMPN di Pesisir Selatan, sehingga belum semua guru mendapatkan pelatihan. Dengan kata lain, belum meratanya pelatihan penilaian pada Kurikulum 2013. Oleh karena itu, pentingnya diadakan pelatihan perancangan penilaian pada Kurikulum 2013. Kegiatan ini dilaksanakan dalam tiga tahapan yaitu persiapan, pelaksanaan, dan penyelesaian. Tahap persiapan dilakukan dengan melakukan koordinasi dengan Pihak SMPN di Pesisir Selatan, survey ke lokasi pelaksanaan pengabdian, menetapkan lokasi pengabdian, dan persiapan teknis pelatihan dan instrumen. Tahap pelaksanaan dilakukan dengan tiga metode yaitu ceramah dan pelatihan, dan latihan merancang penilaian pada Kurikulum 2013, Tahapan terakhir menganalisis angket dan hasil kerja guru untuk membuat laporan. Hasil kegiatan pelatihan menunjukkan bahwa setelah melakukan pelatihan dihasilkan bahwa $84 \%$ guru memahami perancangan penilaian pada Kurikulum 2013 diperolezh melalui angket yang diberikan kepada peserta. Guru sudah bisa merancang penilaian kurikulum 2013 yang benar.
\end{abstract}

Kata kunci: Profesionalisme guru matematika, Penilaian Pada Kurikulum 2013.

\begin{abstract}
Situation analysis in the field illustrates that the assessment used by MTS / SMP Mathematics teachers in the 2013 curriculum has not been implemented optimally. One of the causes is the lack of understanding of MTS / SMP Mathematics teachers about the assessment in the 2013 curriculum. In addition, because there are too many SMP teachers in the South Coast, so not all teachers have received training. In other words, the prevalence of assessment training in the 2013 Curriculum. Therefore, the importance of conducting assessment design training in the 2013 Curriculum. This activity was carried out in three stages, namely preparation, implementation, and completion. The preparatory phase is carried out by coordinating with the State Junior High School in the South Coast, surveying the location of service delivery, determining the location of service, and technical preparation of training and instruments. The implementation phase is carried out with three methods, namely lecture and training, and exercises to design the assessment in the 2013 Curriculum, the last stage is analyzing the questionnaire and the work of the teacher to make a report. The results of the training activities showed that after conducting the training it was produced that $84 \%$ of teachers understood the design of the assessment in the 2013 Curriculum was obtained through questionnaires given to participants. Teachers have been able to design the 2013 curriculum assessment correctly.
\end{abstract}

Keywords: Professionalism of mathematics teachers, Assessment in the 2013 curriculum 


\section{PENDAHULUAN}

Matematika merupakan salah satu pelajaran yang dianggap menakutkan oleh peserta didik (Amir, 2015; Astuti \& Leonard, 2015; Umar, 2012). Akan tetapi anggapan ini bisa dirubah jika seorang pendidik mampu menciptakan lingkungan belajar yang menyenangkan. Selain itu, peserta didik juga membutuhkan motivasi yang tinggi dalam setiap kegiatan pembelajaran sehingga mereka bisa focus dalam pembelajaran (Aritonang, 2008; Suprihatin, 2015). Salah satu motivasi yang bisa dilakukan guru yaitu dengan melakukan penilaian di setiap kegiatan peserta didik dalam pembelajaran. Penilaian yang diharapkan memotivasi peserta didik telah diatur oleh Kurikulum 2013 (Setiadi, 2016). Penilaian yang dimaksud penilaian yang berisikan penilaian kognitif, penilain afektif dan penilaian psikomotor.

Penilaian kognitif merupakan penilaian pengetahuan peserta didik tentang materi yang dipelajari (Gunawan \& Palupi, 2016; Nurbudiyani, 2013; Rosa, 2015; Sujiono, Zainal, Rosmala, \& Tampiomas, 2014). Tentunya seorang pendidik harus memberikan penilaian di setiap pertemuan akan tetapi di temui pada lapangan yaitu pada beberapa MTS/SMP di Pesisr Selatan bahwa pendidik maata pelajaran Matematika sering tidak memberikan penilaian kognitif pada setiap pertemuan. Hal ini disebabkan guru masih kurang memahami makna dari penilaian pada Kurukulum 2013. Hal ini juga didukung oleh hasil temuan dari jurnal dengan judul "Pelaksanaan Penilaian Pada Kurikulum 2013" yang dil- akukan oleh Hari Setiadi, yang juga mengunggakan pendidik masih kurang paham terhadap penilaian pada Kurikulum 2013.

Kurikulum 2013 menginginkan terbentuknya karakter peserta didik atau dengan kata lain tidak hanya cerdas akan tetapi juka bersikap yang baik dengan harapan seimbangnya antara IQ, SQ dan EQ (Hamsah, 2018; Johansyah, 2017). Hal ini difasilitasi dengan diadakannya penilaian afektif/ sikap peserta didik. Dengan dinilainya sikap/ tindakan peserta didik dalam pembelajaran tentunya akan memotivasi mereka untuk aktif dalam pembelajaran (Nasional, 2008; Qomari, 2008). Akan tetapi karena kurang pahamnya peserta didik tentang bagaimana penilaian afektif seharusnya, sehingga pendidik lebih memilih tidak melaksanakannya. Artinya penilaian pada kurikulum 2013 tidak terlaksana sebagaimana mestinya. Hal ini juga diungkapkan dalam jurnal "Problematika dalam penerapan penilaian Kurikulum 2013 bagi guru” yang ditulis oleh Aprilia Wisudaningrum.

Peserta didik dituntut untuk aktif dalam pembelajaran pada Kurikulum 2013. Pendidik hanya menfasilitasi saja, dengan membimbing peserta didik dalam belajar. Kurikulum 2013 juga menuntut peserta didik memiliki keterampilanketerampilan di setiap materi pembelajaran (Choridah, 2013). Untuk itu, pendidik wajib memotivasi peserta didik mengembangkan keterampilan-keterampilan yang dimiliki dengan cara menciptakan suasana belajar aktif dan melakukan penilaian keterampilan/psikomotor. 
Peningkatan Profesional Guru....(Wan Nazir, Nita Putri Utami)85

Namun kenyataannya yang ditemui di beberapa MTS/SMP di Pesisr Selatan pendidik mata pelajaran Matematika masih ada yang tidak melakukan penilaian psikomotor hal ini juga disebkan masih kurang memahami bagaimana penilaian psikomotor pada Kurikulum 2013. Berdasarkan wawancara dengan beberapa pendidik mata pelajaran Matematika MTS/SMP di Pesisir Selatan, mereka mengungkapkan bahwa jarang mendapatkan pelatihan-pelatihan penilaian pada Kurikulum 2013. Sedikitnya pelatihan tentang penilaian Kurikulum 2013 membuat mereka kurang memahami cara merancang dan melaksanakan penilaian.

Berdasarkan masalah-masalah yang di atas, maka perlu diadakan suatu kegiatan pelatihan yang memberikan pengetahuan kepada pendidik tentang perancangan dan pelaksanaan penilaian pada Kurikulum 2013. Untuk itu dalam rangka pemenuhan tugas tridarma perguruan tinggi, selaku dosen matematika di Fakultas Tarbiyah dan Keguruan UIN Imam Bonjol Padang penulis ingin mengabdikan ilmu yang penulis miliki dengan Mengadakan pengabdian kepada masyarakat dalam bentuk: "Peningkatan Profesionalisme Guru Matematika MTS/SMP Di Pesisir Selatan Melalui Pelatihan Merancang Penilaian Pada Kurikulum 2013".

Pelatihan ini bermanfaat bagi guru untuk mengembangkan dan menguasai cara merancang dan melaksanakan penilaian pada kurikulum 2013.
Bagi guru Matematika MTS/SMP di Pesisir Selatan pelatihan ini bermanfaat agar terlakasananya penilaian pada kurikulum 2013 yang optimal sesuai dengan Permen no 23 Tahun 2016 tentang Standar Penilaian.

Penilaian (assesment) memiliki peran yang sangat penting dalam pembelajaran. Menurut (Majid \& Firdaus, 2014; Muchtar, 2010; Sani, 2016; Sutama, Sandy, \& Fuadi, 2017), penilaian (assesment) adalah proses pengumpulan berbagai data yang bisa memberikan gambaran perkembangan belajar peserta didik (Sumintono \& Widhiarso, 2015; Wijayanti, 2014). Penilaian (assesment) hasil belajar peserta didik oleh guru dimaksud untuk mengukur kompetensi atau kemampuan tertentu terhadap kegiatan yang telah dilaksanakan dalam kegiatan pembelajaran, sedangkan penilaian untuk mengetahui sikap peserta didik digunakan teknik non tes. Jenis penilaian tes dapat berupa tes tulis, tes lisan, tes kinerja/tes praktik, sedangkan nontes berupa observasi dan penugasan, baik perorangan maupun kelompok, dapat berupa tugas rumah dan/atau projek, produk, portofolio, dan penilaian afektif (Supratiknya, 2012). Teknik penilaian tidak lepas dari jenis instrumen yang digunakan dan aspek yang dinilai dalam rangka mengumpulkan informasi kemajuan belajar, baik yang berhubungan dengan proses maupu hasil belajar, sesuai dengan kompetensi yang harus dikuasai. 
Penilaian kompetensi dilakukan melalui pengukuran indikator-indikator pada setiap kompetensi dasar (Bisri \& Ichsan, 2015; Rusilowati, 2013).

Assesment menuntut tertampilkannya kompetensi dan kreativitas serta inisiatif yang lebih luas dari diri peserta didik. Jika guru hanya menggunakan teknik asesmen yang tidak dapat mengungkapkan penguasaan peserta didik terhadap kompetensi yang diharapkan maka akan terjadi kontradiksi (Ardiana \& Sudarmin, 2015; Prasetyowati, 2012; Suryawan, Binadja, \& Sulistyorini, 2015). Pada salah satu sisi peserta didik dianggap sudah menguasai kompetensi yang diharapkan, tetapi sebenarnya peserta didik belum menguasai kompetensi tersebut.

Fungsi penilaian hasil belajar meliputi: (1) menggambarkan seberapa dalam seorang telah menguasai suatu kompetensi tertentu (2) mengevaluasi (3) menemukan kesulitan belajar (4) menemukan kelemahan dan kekurangan proses pembelajaran (5) kontrol bagi guru dan sekolah tentang kemajuan . Jadi dengan adanya penilaian, proses pembelajaran, teknik penilaian yang digunakan bisa ditentukan apakah sudah tepat atau tidak. Contohnya, jika ditemukan banyak peserta didik yang belum tuntas dibandingkan yang tuntas maka guru bisa memperbaikinya.

Menurut Alpasiri dan Chandra (2009: 12) penilaian hasil belajar pada jenjang pendidikan dasar dan menengah didasarkan pada prinsipprinsip sebagai berikut. a) Sahih, berarti penilaian didasarkan pada data yang mencerminkan kemampuan yang diukur.

b) Objektif, berarti penilaian didasarkan pada prosedur dan kriteria yang jelas, tidak dipengaruhi subjektivitas penilai.

c) Adil, berarti penilaian tidak menguntungkan atau merugikan karena berkebutuhan khusus serta perbedaan latar belakang agama, suku, budaya, adat istiadat, status sosial ekonomi, dan jender.

d) Terpadu, berarti penilaian oleh pendidik merupakan salah satu komponen yang tak terpisahkan dari kegiatan pembelajaran.

e) Terbuka, berarti prosedur penilaian, kriteria penilaian, dan dasar pengambilan keputusan dapat diketahui oleh pihak yang berkepentingan.

f) Menyeluruh dan berkesinambungan , berarti penilaian oleh pendidik mencakup semua aspek kompetensi dengan menggunakan berbagai teknik penilaian yang sesuai, untuk memantau perkembangan kemampuan .

g) Sistematis, berarti penilaian dilakukan secara berencana dan bertahap dengan mengikuti langkah-langkah baku.

h) Beracuan criteria, berarti penilaian didasarkan pada ukuran pencapaian kompetensi yang ditetapkan, bukan didasarkan pada posisi di dalam kelompoknya.

i) Akuntabel, berarti penilaian dapat dipertanggungjawab baik dari segi teknik, prosedur, maupun hasilnya. 
Jadi dapat disimpulkan penilaian dalam pembelajaran matematika idealnya, mencakup penilaian pengetahuan, penilaian sikap dan penilaian keterampilan. Berikut penjelasan dari setiap penilaian dalam pembelajaran matematika.

\section{a. Penilaian Kognitif (Pengetahuan)}

Pengetahuan merupakan kemasmpuan peserta didik memahami dalam memahami materi yang diberikan guru. Menurut (Majid, 2014) pendidik menilai kompetensi pengetahuan melalui tes tertulis, tes lisan dan penugasan.

1) Instrumen tes tulis berupa soal pilihan ganda, isian, jawaban singkat, benar-salah, menjodohkan, dan uraian. Instrumen uraian dilengkapi pedoman penskoran.

2) Instrumen tes lisan berupa daftar pertanyaan

3) Instrumen penugasan berupa pekerjaan rumah dan/atau projek yang dikerjakan secara individu atau kelompok sesuai dengan karakteristik tugas

Pada pelatihan yang akan diberikan untuk penilaian pengetahuan akan dikembangkan instrumen tes terulis berupa tes ulangan harian. b. Penilaian afektif (sikap)

Kompetensi sikap dalam pembelajaran diharapkan terjadi perubahan yang lebih baik dari sebelum dan sesudah mengikuti pembelajaran. Menurut (Majid, 2014) pendidik melakukan penilaian kompetensi sikap melalui observasi, penilaian diri, penilaian "teman sejawat (peer evalution) oleh peserta didik dan jurnal. Instrumen yang digunakan untuk observasi, penilaian diri, dan penilaian antar peserta didik adalah daftar cek atau skala penilaian (rating scale) yang disertai rubrik, sedangkan pada jurnal berupa catatan pendidik.

1) Observasi merupakan teknik penilaian yang dilakukan secara berkesinambungan dengan menggunakan indera, baik secara langsung maupun tidak langsung dengan menggunakan pedoman observasi yang berisi sejumlah indikator prilaku yang diamati.

2) Penilaian diri merupakan teknik penilaian dengan cara meminta peserta didik untuk mengemukakan kelebihan dan kekurangan dirinya dalam konteks pencapaian kompetensi. Instrumen yang digunakan berupa lembar penilaian diri.

3) Penilaian antar peserta didik merupakan teknik penilaian dengan cara meminta peserta didik untuk saling menilai terkait dengan pencapaian kompetensi. Instrumen yang digunakan berupa lembar penilaian antar peserta didik.

4) Jurnal merupakan catatan pendidik di dalam dan di luar kelas yang berisi informasi hasil pengamatan tentang kekuatan dan kelemahan yang berkaitan dengan sikap dan prilaku peserta didik.

Pada pelatihan yang akan diberikan untuk penilaian sikap akan dikembangkan instrumen berupa lembar observasi. Lembar observasi dirancang sedemikian sehingga dapat menilai sikap yang seharusnya muncul dalam pembelajaran. 
c. Penilaian Psikomotor (keterampilan)

Keterampilan merupakan salah satu komponen penting yang harus dimiliki peserta didik setelah mengikuti kegiatan pembelajaran. Menurut (Majid, 2014) pendidik menilai kompetensi keterampilan melalui penilaian kinerja, yaitu penilaian yang menuntut mendemosntrasikan suatu kompetensi tertentu dengan menggunakan tes praktik berupa presentasi, diskusi atau bertanya, projek, dan penilaian portofolio. Instrumen yang digunakan berupa daftar cek atau skala penilaian (rating scale) yang dilengkapi rubrik.

1) Tes praktik adalah penilaian yang menuntut respon berupa keterampilan melakukan suatu aktivitas atau prilaku sesuai dengan tuntutan kompetensi. Meliputi presentasi, diskusi dan bertanya. Presentasi mengungkapkan kerja peserta didik tentang tugas yang diberikan, mendemonstrasikan apa yang mereka lakukan dan mengambil kesimpulan dari apa yang mereka pelajari. Diskusi mengungkapkan keaktifan peserta didik dalam bekomunikasi pada kerja kelompok.

2) Projek adalah tugas-tugas belajar (learning tasks) yang meliputi kegiatan perancangan, pelaksanaan, dan pelaporan secara tertulis maupun lisan dalam waktu tertentu.

3) Penilaian portofolio adalah penilaian yang dilakukan dengan cara menilai kumpulan seluruh karya dalam bidang tertentu yang bersifat reflektif-integratif untuk mengetahui minat, perkembangan, prestasi, dan/atau kreativitas dalam kurun waktu tertentu.

Pada penilaian yang akan diberikan untuk penilaian keterampilan akan dikembangkan teknik penilaian presentasi. Guru akan menilai peserta didik berdasarkan keterampilan dalam presentasi dengan mengisi lembar observasi yang berisi kriteria penilaian presentasi.

\section{METODE PENELITIAN}

\section{Jenis Penelitian}

Penelitian ini dirancang dengan menggunakan penelitian deskriptif kuantitatif (Arikunto, 2002). Penelitian ini bertujuan untuk mengetahui kemampuan guru matematika SMP Pesisir Selatan dalam merancang penilaian pada kurikulum 2013 setelah melaukan penelitian.

\section{Waktu dan Tempat Penelitian}

Penelitian ini dilaksanakan di SMPN 02 Bayang pada tanggal 10 September 2018.

\section{Populasi dan Sampel}

Populasi dalam penelitian ini adalah guru Matematika SMPN Pesisir Selatan. Sedangkan yang menjadi sampel Guru MGMP Matematika SMPN Pesisir Selatan yang ditunjuk oleh Dinas Pendidikan Pesisir Selatan terdiri dari 30 orang.

\section{Prosedur}

Secara umum prosedur penelitian terdiri atas empat tahap, yaitu tahap persiapan, pelaksanaaan, penutup, dan tahap evaluasi. Di 
Peningkatan Profesional Guru....(Wan Nazir,Nita Putri Utami)89

bawah ini akan dijelaskan mengenai tiap-tiap tahap.

Penelitian ini diawali dengan pmeberian pelatihan Perancangan Penilaian Pada Kurikulum 2013 bagi guru-guru SMPN di Kabupaten Pesisir Selatan dan diakhiri dengan latihan perancangan penilaian tersebut yang menghasilkan suatu produk penilaian. Agar kegiatan pelatihan Perancangan Penilaian Pada Kurikulum 2013 ini dapat berjalan lancar maka setiap peserta harus membawa laptop/note book. Kegiatan pelatihan ini dilakukan dalam bentuk workshop karena peserta diminta untuk merancang penilaian yang telah dihasilkannya dibawah bimbingan dan pendampingan dari tim Dosen Tadris Matematika dan Narasumber. Untuk itu tim memberikan format penilaian ke laptop peserta.

Adapun metode pemberian pelatihan yang digunakan adalah :

1. Metode ceramah. Metode ceramah dipilih untuk memberikan penjelasan tentang penilaian pada Kurikulum 2013 dan memotivasi guru-guru agar merancang bagaimana penilaian yang benar

2. Metode tanya jawab, digunakan untuk memberikan kesempatan kepada peserta pelatihan untuk menanyakan hal-hal yang belum dipahaminya atau meminta penjelasan lebih dalam tentang sesuatu yang ingin diketahuinya. Metode tanya jawab sangat penting bagi para peserta pelatihan, baik di saat menerima penjelasan tentang penilaian kurikulum 2013 serta saat mempraktekkannya. Metode ini memungkinkan

3. Metode Simulasi, metode ini sangat penting diberikan kepada para peserta pelatihan untuk memberikan kesempatan mempraktekan materi pelatihan yang diperoleh. Dengan harapan, peserta pelatihan akan benarbenar menguasai materi pelatihan yang diterima, mengetahui tingkat kemampuannya menerapkan kegiatan perancangan penilaian pada kurikulum 2013 secara tehnis dan kemudian mengidentifikasi kesulitankesulitan (jika masih ada) untuk kemudian dipecahkan.

4. Metode Pendampingan, Agar kegiatan ini betul-betul memiliki kontribusi yang signifikan untuk memotivasi dan meningkatkan kemampuan guru MTsN/S dalam merancang penilaian pada kurikulum 2013 yang diakhiri dengan pengisian angket terhadap pemahaman perancangan penilaian pada Kurikulum 2013.

Untuk lebih jelasnya pelaksanaan kegiatan pelatihan dapat dikemukakan sebagai berikut.

\section{Acara Pembukaan .}

- Pembukaan oleh MC

- Pembacaan ayat suci Alquran

- Sepatah kata dan perkenalan dari Dosen Tadris Matematika dan Narasumber, disampaikan oleh Ibu Dr.Nana Seprianti, M.Si

Dalam acara perkenalan ini Tim mengucapkan terimakasih kepada Bapak Kepala 
Dinas Pendidikan Kabupaten Pesisir Selatan dan Ibuk Kepala Sekolah Menengah Pertama Negeri 02 Bayang.

Terimakasih yang tak terhingga juga disampaikan kepada guru-guru yang telah berkenan hadir untuk mengikuti acara ini, mudah-mudahan Allah SWT meredhai kegiatan kita dan apa yang akan kami sampaikan bermanfaat bagi Bapak.ibu/sdr sekalian

Kegiatan pelatihan ini dilakukan dengan mitra pimpinan prodi tadris matematika dan widyasuara di balai diklat keagamaan Padang yang sekaligus berperan sebagai narasumber kegiatan ini:

1. Ibu Dr.Nana Sepriyanti, S.Pd, M.Si

2. Dr. H. Wan Nasir, M.Pd

Dan didampingi oleh tim Dosen Tadris Matematika, yaitu:

1. Ibu Nita Putri Utami, M.Pd

2. Ibu Amalina, M.Si

Kegiatan ini didukung oleh seorang mahasiswa yakni Revy Wuluanuary ( TMM) sebagai teknisi untuk kesuksesan kegiatan ini. Selanjutnya tim memohon kiranya Kepalas SMPN 02 Bayang dapat memberikan sambutan dan membuka acara secara resmi.

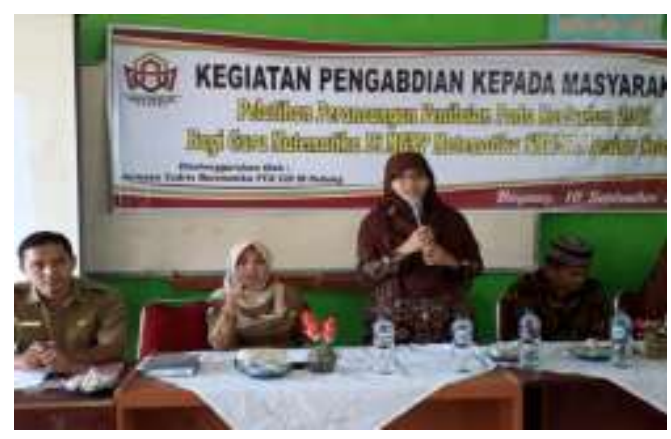

Gambar 1. Sepatah Kata dan Perkenalan Tim Pengabdi
- Sambutan sekaligus membuka acara secara resmi oleh Ibuk Arda Yenni, S.Pd (Kepala SMPN 02 Bayang ).

Kepala SMPN 02 Bayang Ibuk Arda Yenni, S.Pd mengucapkan selamat datang dan terimakasih kepada Tim dan instruktur yang telah berkenan datang dan menjadikan Kepala SMPN 02 Bayang sebagai tempat pelaksanaan pengabdian ini Kami sangat menghargai kepedulian tim terhadap permasalahan yang dihadapi oleh para guru Matematika SMP di Kabupaten Pesisir Selatan. Oleh karena itu kami sangat berterimakasih atas perhatian Ibu-Ibu tim terhadap permasalah yang dihadapi para guru. Ibuk Arda Yenni, S.Pd menutup pidatonya, sambil membuka acara pelatihan dengan resmi dengan membaca Bismilahir Rahmanir Rahim

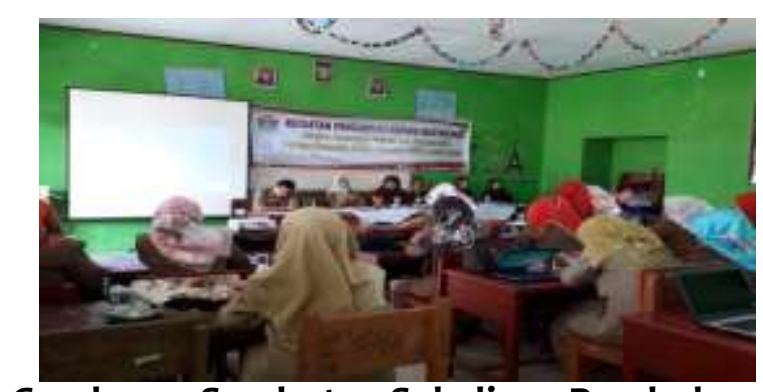

Gambar 2. Sambutan Sekaligus Pembukaan oleh Kepala MTsN

- Doa dipimpin oleh Irwan,S.Pd.I.

Acara pembukaan ini ditutup dengan doa bersama yang dipimpin oleh Irwan,S.Pd.I.

\section{Kegiatan inti.}

Setelah istirahat dan menikmati snack yang telah disediakan, kegiatan pelatihan perancangan 
penilaian pada Kurikulum 2013 dimulai. Adapun materi pelatihan sebagai berikut.

Materi 1 : Pendahuluan Kurikulum 2013 dan Pendidikan Abad 21, disampaikan oleh Dr. $\mathrm{Hj}$. Wan Nasir, M.Pd

Intruktur menyampaikan bahwa kurikulum 2013 memiliki tiga cakupan kompetensi yang harus dikuasi siswa diantaranya pengetahuan, sikap dan keterampilan. Lalu instruktur menjelaskan asal mulanya munculnya Kurikulum 2013. Berikut salah satu slide yang dijelaskan pemateri .

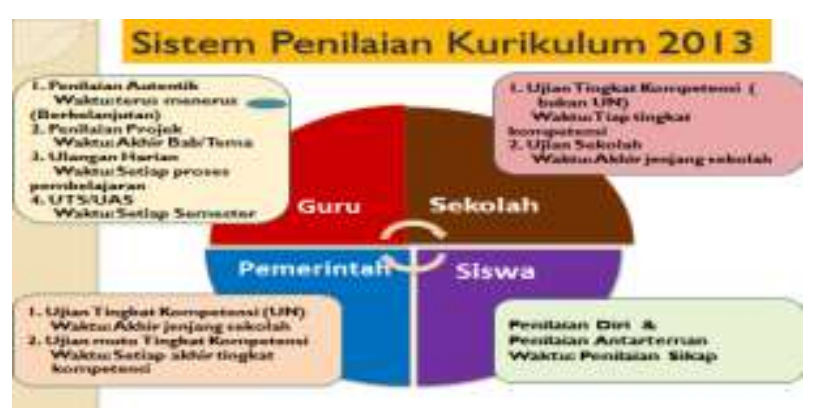

Gambar 3. Ringkasan Materi

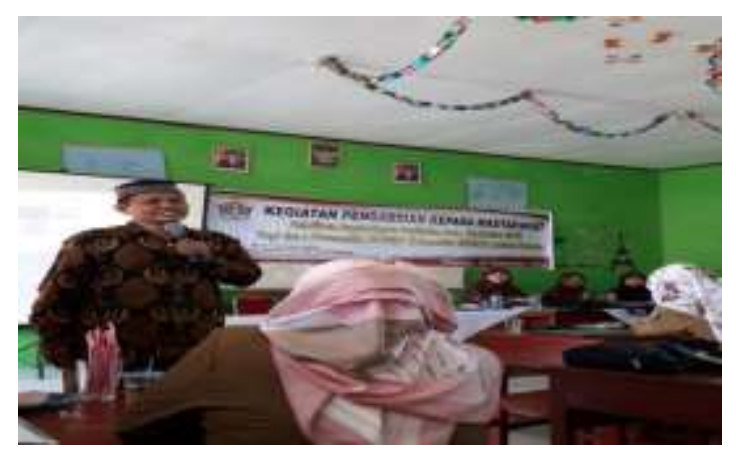

Gambar 4. Instruktur Menyampaikan Pendahuluan Kurikulum 2013 dan Pendidikan Abad 21

\section{Materi 2 : Merancang Penilaian Matematika}

Pada Kurikulum 2013 oleh Ibu Dr.Nana Sepriyanti, S.Pd, M.Si

Mengawali kegitan perancangan penilaian pada kurikulum 2013, instruktur mengcopykan template penilaian pada kurikulum 2013 ke laptop/ notebook semua peserta dalam rangka mem- permudah peserta dalam mengikuti kegiatan pelatihan dan pendampingan ini, Kemudian peserta diminta untuk membuka template perancangan pada kurikulum 2013 di laptop/notebook masing-masing. Selain itu, juga diberikan lembaran yang berisi format penilaian bagi guru yang tidak membawa laptop.

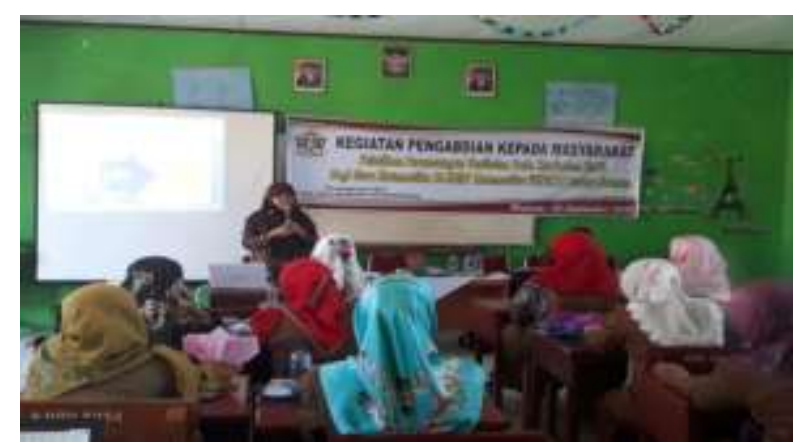

Gambar 5. Instruktur Merancang Penilaian Matematika Pada Kurikulum 2013

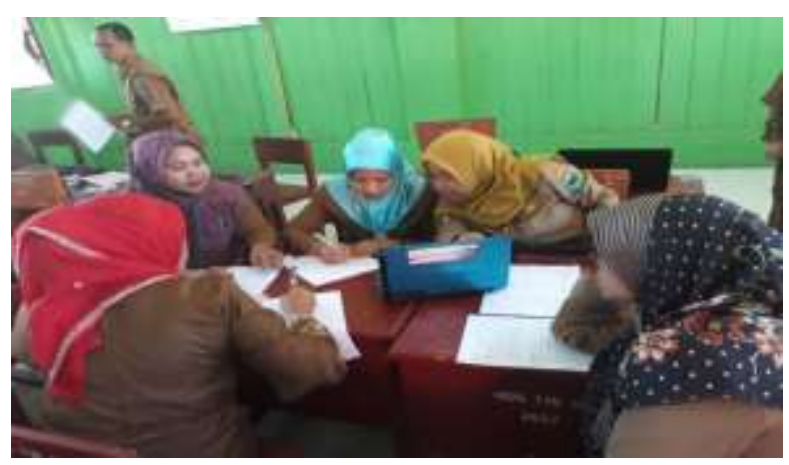

Gambar 7. Peserta Serius Mengerjakan Rancangan Penilaian Pada Krikulum 2013

\section{Penutup}

Acara penutupan dilakukan dengan mengumpulkan semua tugas dalam perancangan penilaian kurikulum 2013. Dan akhirnya dengan mengucapkan Alhamdulillah acara pelatihan dan peerancangan penilaian pada kurikulum 2013 ditutup.

\section{Evaluasi}

Dalam pendidikan, pada awalnya pengertian evaluasi pendidikan selalu dikaitkan 
dengan prestasi belajar siswa. Ralph Tyler (1950) mengatakan bahwa evaluasi merupakan sebuah proses pengumpulan data untuk menentukan sejauh mana, dalam hal apa, dan bagian mana tujuan tercapai.

Secara umum, evaluasi sebagai suatu tindakan atau proses setidak-tidaknya memiliki tiga macam fungsi pokok, diantaranya :

1. Mengukur kemajuan, dalam hal ini setidak-tidaknya ada dua macam kemungkinan hasil yang diperoleh yaitu menggembirakan dan yang tidak menggembirakan.

2. Menunjang penyusunan rencana, dengan adanya hasil yang diperoleh dapat menunjang para evaluator untuk melakukan perencanaan ulang (re-planning) atau perencanan baru. Evaluasi secara berkesinambungan, akan membuka peluang bagi evaluator untuk membuat perkiraan (estimation).

Memperbaiki atau atau melakukan penyempurnaan kembali, atas dasar hasil evaluasi yang diperoleh, evaluator perlu memperbaiki dan melakukan penyempurnaanpenyempurnaan, perbaikan-perbaikan yang menyangkut organisasi, tata kerja, dan bahkan tujuan organisasi tersebut. Pada kegiatan penelitian ini, evaluasi yang dilakukan dengan mengisi angket pemahaman guru matematika terhadap perancangan penilaian kurikulum 2013 setelah melakukan pelatihan.

\section{Data, Intrumen, dan Teknik Pengumpulan Data}

Data primer diperoleh melalui data hasil angket terhadap pemahaman perancangan penilaian pada kurikulum 2013 setelah melakukan pelatihan. Data sekunder, yaitu data tentang jumlah Guru matematika SMPN Pesisir Selatan yang menjadi populasi dan sampel. Data sekunder ini diperoleh dari Dinas Pendidikan Pesisir Selatan Angket yang diisi terdari atas 36 butir pernyataan yang terdiri atas masingmasing 12 pernyataan penilaian kognitif, penilaian afektif dan penilaian psikomotor.

\section{Teknik Analisis Data}

Analisis data angket dilakukan dengan beberapa langkah sebagai berikut.

a. Memberikan skor jawaban dengan kriteria berdasarkan skala Likert yang dimodifikasi dari (Riduwan, 2007) dengan 4 alternatif yang telah ditentukan.

b. Menentukan jumlah skor dari masing-masing responden dengan menjumlahkan semua skor yang diperoleh dari masing-masing indikator.

c. Penentuan nilai agket dengan cara:

Nilai angket (kognitif/afektif/psikomotor) = $\frac{j u m l a h \text { skor yang diperoleh }}{\text { jumlah skor tertinggi }} \times 100 \%$

Memberikan penilaian validitas dengan kriteria seperti yang dikemukakan oleh (Riduwan, 2007) yang telah dimodifikasi.

$$
\begin{aligned}
& 0 \%-20 \%=\text { Tidak paham } \\
& 21 \%-40 \%=\text { Kurang paham } \\
& 41 \%-60 \%=\text { Cukup paham } \\
& 61 \%-80 \%=\text { paham } \\
& 81 \%-100 \%=\text { Sangat paham }
\end{aligned}
$$

d. Menyajikan dalam bentuk diagram batang untuk setiap kemampuan 


\section{HASIL DAN PEMBAHASAN}

Penilaian pada Kurikulum Tingkat Satuan Pendidikan 2006 belum terlalu menekankan penilaian afektif dan psikomotor, akan tetapi sudah mengarah ke penilaian tersebut. Pada Kurikulum 2013, sudah diatur dan diwajibkan dilaksankannya penilaian pada tiga aspek yaitu, pengetahuan, sikap dan keterampilan. Hal ini terlihat dari adanya kompetensi Inti dan kompetensi dasar yang memuat ketiga aspek tersebut. Karena merupakan hal baru, maka banyaknya guru yang belum mampu merancang penilaian kurikulum 2013.

Pada pelaksanaan pelatihan perancangan penilaian pada Kurikulum 2013. Pelatihan ini dipilih karena belum optimalnya perancangan penilaian disekolah. Hal ini karena terlalu banyak SMPN di Pesisir Selatan, jadi pembagian pelatihan kurang merata.

Angket yang diberikan kepada guru yang telah mendapatkan pelatihan mencankup tentang pemahaman guru terhadap penilaian kognitif, penilaian afektif, dan penilaian psikomotor yang telah diberikan.

a. Penilaian Kognitif Pada Kurikulum 2013

Untuk angket penilaian kognitif diberikan 12 butir pernyataan. Pernyataan-pernyataan pada angket penilaian kognitif berisi tentang bagaimana pemahaman guru terhadap perancangan penilaian kognitif, pelaksanaan penilaian kognitif dan pengolahan penilaian kognitif. Dari hasil penyebaran angket untuk penilaian kognitif dari 30 orang guru ditambah 1 orang kepala sekolah ditunjukkan seperti pada Gambar 8.

Pada diagram terlihat bahwa untuk perancangan penilaian kognitif guru sudah sangat paham, begitu juga dengan pelaksanaan. Akan tetapi pada grafik pengolahan terjadi penurunan atau grafik yang paling rendah. Artinya beberapa guru masih kurang paham pada pengolahan penilaian kognitif. Mereka kesulitan pada pengolahan penilaian kognitif disebabkan banyaknya guru masih belum memahami tentang penggunaan rubrik penskoran. Mereka sudah mampu merancang rubrik penskoran ini terlihat dari hasil grafik yang paling tinggi, akan tetapi pada penggunaan masih banyak yang ragu, antara bobot, skala dan skor. Kemampuan melakukan penilaian merupakan salah satu kemampuan professional yang harus dimiliki guru sesuai Undang-undang Nomor 14 Tahun 2005.

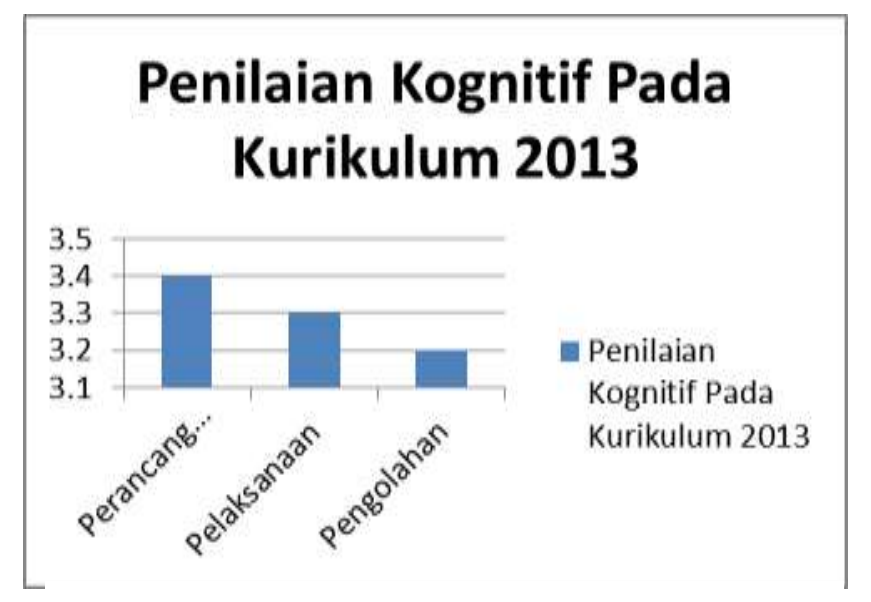

\section{Gambar 8. Penilaian Kognitif Pada Kurikulum 2013}

b. Penilaian Afektif Pada Kurikulum 2013

Untuk angket penilaian kognitif diberikan 12 butir pernyataan. Pernyataan-pernyataan pada angket penilaian afektif berisi tentang 
bagaimana pemahaman guru terhadap perancangan penilaian afektif, pelaksanaan penilaian afektif dan pengolahan penilaian afektif. Dari hasil penyebaran angket untuk penilaian afektif dari 30 orang guru ditambah 1 orang kepala sekolah ditunjukkan seperti pada Gambar 9.

Pada diagram terlihat bahwa untuk perancangan penilaian afektif guru sudah sangat paham, begitu juga dengan pengolahannya. Akan tetapi pada grafik pelaksanaan terjadi penurunan atau grafik yang paling rendah. Artinya beberapa guru masih kurang paham pada pelaksanaan penilaian afektif. Mereka kesulitan pada pelaksanaan penilaian afektif disebabkan banyaknya guru masih susah melakukan observasi kepada setiap peserta didik pada saat pembelajaran. Pada saat pembelajaran, mereka menjadi fasilitator dalam pembelajaran, jadi sering lupa melakukan penilaian sikap. Selain itu mereka juga mengungkapkan unsur subjektifitas sangat mempengaruhi proses penilaian yang sangat susah dihindari.

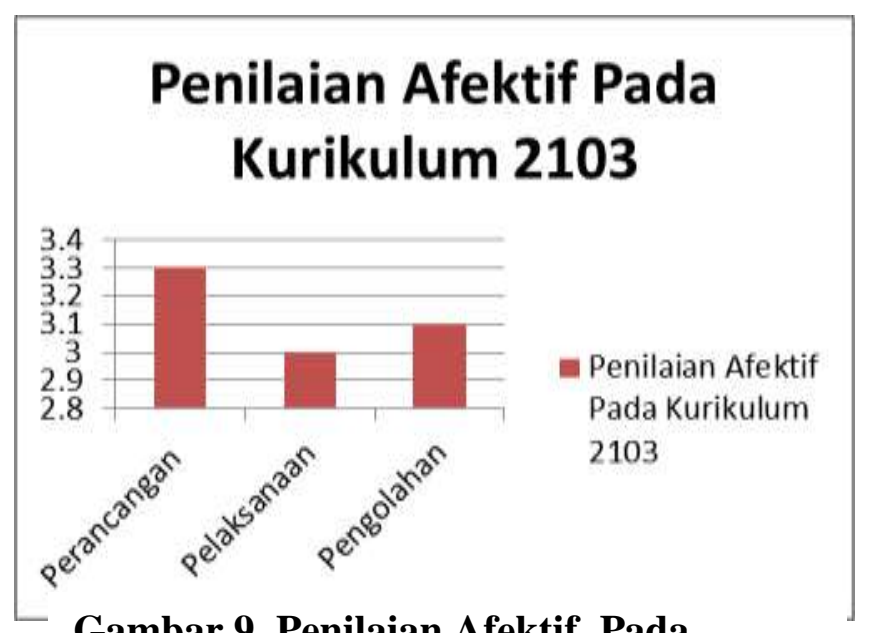

Kurikulum 2013 c. Penilaian Psikomotor Pada Kurikulum 2013

Untuk angket penilaian psikomotor diberikan 12 butir pernyataan. Pernyataanpernyataan pada angket penilaian psikomotor berisi tentang bagaimana pemahaman guru terhadap perancangan penilaian psikomotor, pelaksanaan penilaian psikomotor dan pengolahan penilaian psikomotor. Dari hasil penyebaran angket untuk penilaian psikomotor dari 30 orang guru ditambah 1 orang kepala sekolah ditunjukkan seperti pada Gambar 10.

Pada diagram terlihat bahwa untuk perancangan penilaian afektif guru sudah sangat paham, begitu juga dengan pelaksanaan dan pengolahan. Dari ketiga pelatihan penilaian pada Kurikulum 2013 yang diberikan, penilaian psikomotor merupakan penilaian yang paling dipahami baik dari segi perancangan, pelaksanaa dan pengolahan.

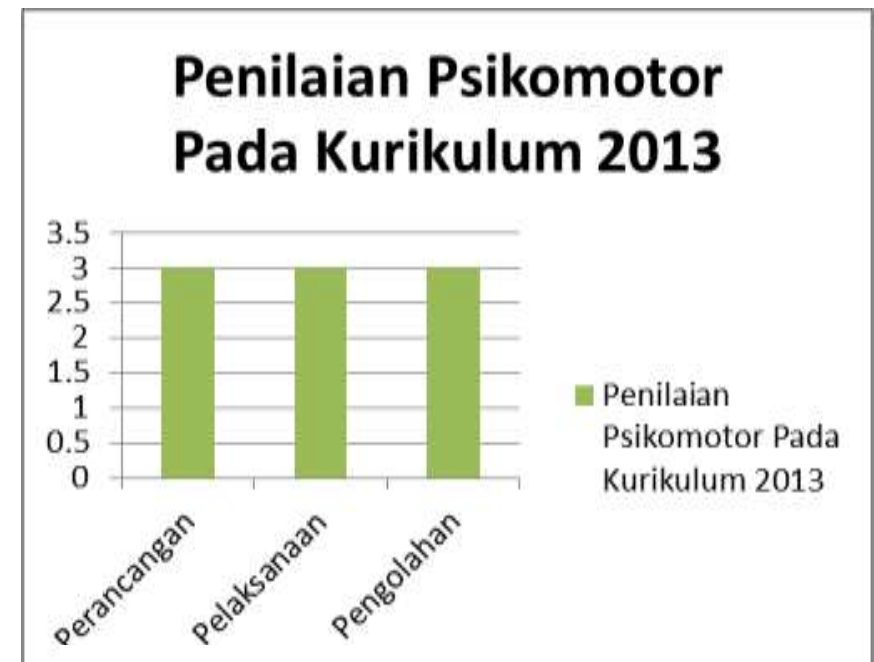

\section{Gambar 10. Penilaian Psikomotor Pada Kurikulum 2013}

Kompetensi guru Matematika dalam merancang Penilaian Pada Kurikulum 2013 pada kategori sangat baik berbanding lurus dengan persepsi guru terhadap pelatihan ini. Metode ceramah, demonstrasi dan praktek yang 
Peningkatan Profesional Guru....(Wan Nazir, Nita Putri Utami)95

digunakan selama pelaksanaan pelatihan sangat membantu peserta dalam memahami materi dan memiliki keterampilan dalam perancangan penilaian pada kurikulum 2013

\section{SIMPULAN DAN SARAN}

\section{Simpulan}

1. Adanya kesesuaian materi dengan kebutuhan guru-guru SMP untuk meningkatkan profesionalitasnya.

2. Adanya respon yang positif dari peserta mengingat kegiatan pengabdian ini merupakan kebutuhan guru dalam rangka peningkatan profesionalitasnya.

3. Sebagian besar (84\%) peserta telah memahami konsep perancangan penilaian kurikulum 2013.

4. Pada penilaian kognitif untuk perancangan, pelaksanaan dan pengolahan sudah dapat dikategorikan paham, presentasi yang paling rendah diperoleh pada pegolahan penilaian kognitif.

5. Pada penilaian afektif untuk perancangan, pelaksanaan dan pengolahan sudah dapat dikategorikan paham, presentasi yang paling rendah diperoleh pada pelaksanaan penilaian afektif.

6. Pada penilaian psikomotor untuk perancangan, pelaksanaan dan pengolahan sudah dapat dikategorikan paham.

\section{Saran}

1. Melihat antusias dan semngat peserta pelatihan dalam mengikuti kegiatan ini, kepada FTK UIN Imam Bonjol Padang untuk bisa memfasiliasi pelatihan pada massa yang akan datang.

2. Kepada peserta pelatihan (guru, orang tua, dan siswa) diharapkan dapat membagi ilmunya kepada yang belum dapat kesempatan mengikuti pelatihan

3. Agar dilakukan pelatihan lanjutan untuk beberapa tahap yang masih rendah, seperti pengolahan penilaian kognitif dan pelaksanaan penilaian afektif.

\section{DAFTAR PUSTAKA}

Amir, A. (2015). Kemampuan Penalaran dan Komunikasi dalam Pembelajaran Matematika. Logaritma, 2(01).

Ardiana, M., \& Sudarmin, S. (2015). Penerapan Self Assessment untuk Analisis Keterampilan Berpikir Tingkat Tinggi Siswa. Jurnal Inovasi Pendidikan Kimia, 9(1).

Arikunto, S. (2002). Metodologi penelitian. Jakarta: PT. Rineka Cipta.

Aritonang, K. T. (2008). Minat dan motivasi dalam meningkatkan hasil belajar siswa. Jurnal pendidikan penabur, 7(10), 11-21.

Alpasiri, Junianto dan Rudi Chandra.2009. Assessment and Teaching. Sukabina Press : Padang

Astuti, A., \& Leonard, L. (2015). Peran Kemampuan Komunikasi Matematika Terhadap Prestasi Belajar Matematika Siswa. Formatif: Jurnal Ilmiah Pendidikan MIPA, 2(2).

Bisri, H., \& Ichsan, M. (2015). Penilaian otentik dengan teknik nontes di sekolah Dasar. Jurnal Sosial Humaniora, 6(2), 81-93.

Choridah, D. T. (2013). Peran pembelajaran berbasis masalah untuk meningkatkan kemampuan komunikasi dan berpikir kre- 
atif serta disposisi matematis siswa SMA. Infinity Journal, 2(2), 194-202.

Gunawan, I., \& Palupi, A. R. (2016). Taksonomi Bloom-revisi ranah kognitif: kerangka landasan untuk pembelajaran, pengajaran, dan penilaian. Premiere educandum: jurnal pendidikan dasar dan pembelajaran, 2(02).

Hamsah, M. (2018). Membangun Karakter Bangsa (Master's Thesis). Universitas Islam Indonesia.

Johansyah, J. (2017). Pendidikan Karakter Dalam Islam; Kajian dari Aspek Metodologis. Jurnal Ilmiah Islam Futura, 11(1), 85-103.

Majid, A. (2014). Implementasi kurikulum 2013: kajian teoretis dan praktis. Interes.

Majid, A., \& Firdaus, A. S. (2014). Penilaian autentik proses dan hasil belajar. Bandung: PT Remaja Rosdakarya.

Muchtar, H. (2010). Penerapan Penilaian Autentik dalam Upaya Peningkatan Mutu Pendidikan. Jurnal Pendidikan Penabur, 14(9), 68-76.

Nasional, D. P. (2008). Pengembangan Perangkat Penilaian Afektif. Direktorat Jenderal Manajemen Pendidikan Dasar dan Menengah, Direktorat ....

Nurbudiyani, I. (2013). Pelaksanaan Pengukuran Ranah Kognitif, Afektif, dan Psikomotor pada Mata Pelajaran IPS Kelas III SD Muhammadiyah Palangkaraya. Anterior Jurnal, 13(1), 88-93.

Prasetyowati, D. (2012). Pengembangan Perangkat Pembelajaran Matematika Berbasis Humanistik Dan Konstruktivisme Dengan Pendekatan Savi (Somatic Auditory Visual Intellectual) Berbantu Cd Interaktif Materi Segi Empat Kelas VII. AKSIOMA: Jurnal Matematika dan Pendidikan Matematika, 3(2), 17-27.

Qomari, R. (2008). Pengembangan instrumen evaluasi domain afektif. Insania, 13(1), 87109.
Riduwan, M. B. A. (2007). Skala pengukuran variabel-variabel penelitian. Alfabeta. Bandung.

Rosa, F. O. (2015). Analisis Kemampuan Siswa Kelas X pada Ranah Kognitif, Afektif dan Psikomotorik. Omega: Jurnal Fisika dan Pendidikan Fisika, 1(2), 24-28.

Rusilowati, A. (2013). Pengembangan Instrumen Nontes. Makalah. Seminar Nasional Evaluasi Pendidikan Di Universitas Negeri Semarang.

Sani, R. A. (2016). Penilaian Autentik. Bumi Aksara.

Setiadi, H. (2016). Pelaksanaan penilaian pada Kurikulum 2013. Jurnal Penelitian dan Evaluasi Pendidikan, 20(2), 166-178.

Sujiono, Y. N., Zainal, O. R., Rosmala, R., \& Tampiomas, E. L. (2014). Metode pengembangan kognitif.

Sumintono, B., \& Widhiarso, W. (2015). Aplikasi pemodelan rasch pada assessment pendidikan. Trim Komunikata.

Supratiknya, A. (2012). Penilaian hasil belajar dengan teknik nontes. Yogyakarta: Universitas Sanata Dharma.

Suprihatin, S. (2015). Upaya guru dalam meningkatkan motivasi belajar siswa. Jurnal Pendidikan Ekonomi UM Metro, 3(1), 7382.

Suryawan, A., Binadja, A., \& Sulistyorini, S. (2015). Pengembangan Instrumen Performance Assessment Praktikum Bervisi Sets Untuk Mengukur Keterampilan Proses Sains. Journal of Primary Education, 4(1).

Sutama, S., Sandy, G. A., \& Fuadi, D. (2017). Pengelolaan Penilaian Autentik Kurikulum 2013 Mata Pelajaran Matematika di SMA. Manajemen Pendidikan, 12(1), 105114. 
Peningkatan Profesional Guru....(Wan Nazir,Nita Putri Utami)97

Umar, W. (2012). Membangun kemampuan komunikasi matematis dalam pembelajaran matematika. Infinity Journal, 1(1), 1-9. dekatan saintifik untuk meningkatkan keterampilan berpikir ilmiah mahasiswa. Jurnal Pendidikan IPA Indonesia, 3(2).

Wijayanti, A. (2014). Pengembangan autentic assesment berbasis proyek dengan pen- 